\title{
Impacts of online formative assessment on EFL students' writing achievement
}

\author{
Ho Bich $\mathrm{Nhu}^{1 *}$, Dang Tan Tin ${ }^{2}$ \\ ${ }^{1}$ Kien Giang University, Vietnam \\ ${ }^{2}$ University of Technology and Education Ho Chi Minh City, Vietnam \\ *Corresponding author: bichnhu1979@gmail.com
}

\begin{tabular}{|c|c|}
\hline ARTICLE INFO & ABSTRACT \\
\hline $\begin{array}{l}\text { DOI:10.46223/HCMCOUJS.so } \\
\text { ci.en.9.1.271.2019 }\end{array}$ & $\begin{array}{l}\text { There have been a number of studies on the effects of } \\
\text { formative assessment on Learning Management System on EFL } \\
\text { writing achievement. Nevertheless, in the context of Vietnam, } \\
\text { little research has been done on education technology that } \\
\text { enhances online formative assessment in teaching writing. In an } \\
\text { attempt to further the previous research nationwide and }\end{array}$ \\
\hline Received: April 9 $9^{\text {th }}, 2019$ & worldwide, this study examined the impacts of formative \\
\hline Revised: June $8^{\text {th }}, 2019$ & assessment on students' writing achievement in a writing course \\
\hline Accepted: July $17^{\text {th }}, 2019$ & $\begin{array}{l}\text { of Learning Management System Schoology. A quasi- } \\
\text { experimental design was carried out among two groups of fifty } \\
\text { undergraduate Vietnamese students over a fifteen-week writing } \\
\text { course using the main activity named online discussion board. The } \\
\text { data analysis from the writing test scores suggested that there was }\end{array}$ \\
\hline Keywords: & a statistically significant difference between the treatment group \\
\hline $\begin{array}{l}\text { formative assessment, online } \\
\text { discussion board, students' } \\
\text { writing achievement }\end{array}$ & $\begin{array}{l}\text { and the control group of participants. It is recommended that } \\
\text { teachers should employ online formative assessment in teaching } \\
\text { writing to help improve writing achievement among EFL learners } \\
\text { in Vietnam and similar contexts. }\end{array}$ \\
\hline
\end{tabular}

\section{Introduction}

Formative assessment has been proved to be an effective tool in improving learners' use of language (Bachman, 1990; Chappuis \& Chappuis, 2007; Cheng, Rogers, \& Hu, 2004; Cowie \& Bell, 1999; Yu \& Li, 2014). Investigating formative assessment studies helped encourage students' achievement (Hattie, 2009, 2012); or enhance students' performance when integrated into teaching (Wiliam, Lee, Harrison, \& Black, 2004). Importantly, employing different formative methods to assess the students during the course would both enhance students' success and encourage their motivation and self-assessment (Black \& William, 1998). Especially, in teaching writing, this type of assessment can help teachers "to gauge the effectiveness of their instructional practices, modify instructions as needed, and provide students with feedback on writing strengths and areas in need of further development" (Graham, Harris, \& Hebert, 2011, p. 5). Nowadays, with the advancement and proliferation of cyber applications, and learning management systems bound up with Web 2.0, educators and 
researchers are greatly aware of how computer-assisted assessments can benefit their teaching and evaluation process. Several researchers have noted the advantages of online formative assessments over traditional classroom assessments. A web-based formative assessment strategy can allow students to assess their own progress and understanding at any time. It can also help foster a learner and assessment centered focus through formative feedback and enhance learner engagement with valuable learning experiences (Gikandi, Morrow, \& Davis, 2011).

Despite the increasing application of Web 2.0 in recent years, EFL teachers in Vietnam seem not to make use of the benefits offered by the LMS system. There is still a lack of research on education technology that enhances online formative assessment in teaching writing. In an attempt to further the previous research nationwide and worldwide, this study aims to explore the impacts of formative assessment on students' writing achievement in a writing course on Learning Management System Schoology.

\section{Literature review}

\subsection{Formative assessment}

There are numerous definitions of formative assessment by different aspects. According to Black and Wiliam (1998), formative assessment was defined as all activities performed by the teacher and his students in assessing themselves, which are feedbacks to "modify teaching and learning activities" to meet students' needs. Cowie and Bell (1999) also emphasized formative assessment as the process used by teachers and students to recognize, respond to and improve students' learning. Gipps (1994) defined formative assessment as the process of appraising, judging or evaluating students' work or performance to shape and improve their competence. Furthermore, Kahl (2005) claimed that unlike a simple evaluation device marking the end of instruction used by teachers to measure student grasp of specific topics and skills, a formative assessment is an effective tool to identify misconceptions and mistakes made by students during the learning process.

According to Clarke (2005b), a formative assessment has many key features other than simply good teaching practices. These features mainly focus on the process of students developing their learning and being critical about their goals and abilities. First of all, teachers have to take time to clarify and share learning objectives with students; share knowledge of success criteria and encourage students to be autonomous learners. Next, they provide students with effective, useful and personalized feedback. Finally, they promote students' self and peer evaluations.

Based on the above features of formative assessment, Harsch (2014b) proposed the aims of formative assessment as follows:

a. Feedback and information about the learners' level and learning progress

b. Diagnosis of strengths and weaknesses

c. Exploring learners' potential

d. Feedback on teaching effectiveness, for planning and modifying next steps

e. Reflection by all participants

f. Motivation and improvement/development 


\section{g. Autonomy and learner participation}

As the purposes of formative assessment, Irons (2008) and Harsch (2014b) offered some suggestions for the format of formative assessment feedback including annotated scripts, feedback sheets, marking grids, model answers, statement banks, demonstrations, peer feedback, tutorials, journals and observations. Li's (2012) study mentioned the four types of formative assessment namely self-assessment, peer assessment, teacher assessment and collaborative assessment. Besides, Black and Wiliam (1998) emphasized that formative assessment activities were tools to provide feedback for teachers and students to modify teaching and learning activities they took part in. In this study, the researcher tries to explore just two types of the formative assessment called peer-assessment and self-assessment.

Self-assessment is one of the key elements in formative assessment because it stimulates students to think about the quality of their own work rather than relying on their teacher as the sole source of evaluative judgments. It is really "a necessary skill for lifelong learning" (Boud, 1995, p. 13). In self-assessment, students assess their learning directly. They self-reflect on their study results, evaluate their present performances and set their future goals. Obviously, students have to make their own decisions in their EFL learning.

Peer-assessment allows students to compare their work with that of their peers, and thus helps students to evaluate mutual achievements and outcomes. When permitted to see the strengths and weaknesses of their friends, students are likely to gain more confidence and reduce anxiety in making mistakes.

These two formative assessment activities were mainly adopted to design writing assignments for students during the course. The effects of online formative assessment tools were carefully discussed in the next section.

\subsection{Impacts of online formative assessment on EFL students' writing achievement}

Formative assessment has been emphasized as a feasible way of developing achievement in college English teaching ( $\mathrm{Li}, 2012)$. In the field of language learning, there are numerous studies exploring the impacts of formative assessment on EFL students' writing achievement.

In experimental research conducted in Egypt, Aliweh (2011) examined the effects of electronic portfolios on enhancing Egyptian EFL college students' writing competence and autonomy. Accordingly, sixty-four college students were randomly split into two groups: experimental and control groups. Members of the control group developed traditional paper portfolios whereas their counterparts of the experimental group used the Internet and online resources to develop and present the same essay portfolios. The impacts of the electronic portfolio were measured using the Writing Competence Rating Scale and the Learning Autonomy Scale. The findings revealed that online portfolios did not yield significant effects on students' writing competence and learning autonomy because of different uncontrollable variables in the online environment. Some possible interpretations were given about the distinct characteristics of the Egyptian educational system and students.

Another study in Iran by Ghadi (2016) examined the effects of employing electronic peer assessment on 90 Iranian EFL learners' writing ability and autonomy. Data analysis from questionnaires showed that electronic peer assessment had significant effects on Iranian EFL learners' writing ability. Results of semi-structured interviews indicated that the subjects had 
positive beliefs about the implementation of electronic peer assessment and they felt more responsible to read and assess their classmates' writing. The study finally suggested some pedagogical implementation of using electronic peer assessment in EFL setting.

In 2017, Zainnuri and Cahyaningrum carried out a case study to investigate the effectiveness of online peer review through discussion via Schoology in enhancing the proficiency of EFL college students' argumentative writing at Sebelas Maret University. The findings indicated that online peer review through discussion via Schoology can help improve students' proficiency in higher education about argumentative writing. The results of previous studies showed that formative assessment via the virtual environment increasingly draws the attention of EFL researchers from different learning setting worldwide. This study aims to examine the effects of online formative assessment on EFL learners in Vietnamese context with the hope to maximize its benefits in foreign language teaching and learning.

\subsection{Formative assessment on Schoology Platform}

\subsubsection{What is Schoology?}

Schoology is a website and an app used by teachers and students to share information, resources and files. Initially designed by four college students in 2007, it has become one of the most popular learning management systems which provide digital medium to foster student-tostudent and student-to-teacher interactions within a classroom network. This cloud-based platform is accessible via websites (www.Schoology.com). It is considered as the best education solution for K-12 and higher education, and learning management system categories and as the finalist of best K-12 course or learning management solution and best post-secondary learning management solution categories in 2015 (Schoology, 2015).

In Schoology, students are able to access their assignments, grades, teaching materials, attendance records and teacher feedback on the electronically-submitted task. Communication between teachers and students increased by access to this information and held students' academic responsibilities. By using Schoology, teachers can make collaborative groups, discussion questions or assignments to provide a dynamic interaction between them and their students. For example, students participating in a writing assignment can ask questions and post comments on their classmates' work. They can also provide feedback on any of their friends' writing. Teachers can monitor discussions and give corrective feedback on students' assignments.

\subsubsection{Formative assessment on Schoology Platform}

As a learning management system, Schoology provides a variety of educational tools, such as text/ quiz, online discussion board, assignment or reflective journal. It helps teachers manage media learning material systematically and create dynamic assessments and assignments using a rubric or a checklist (Ardi, 2017). In this study, the main formative assessment tool is the online discussion board.

Discussion board on Schoology is a tool for the teacher to create assignments in the form of discussion. The online discussion provides students a chance to self-assess their writings, find out their mistakes and self-correct the mistakes. When students join a course on Schoology, they are able to get access to their assignments, grades, materials, attendance records and teacher's feedback on their online tasks. The students have introduced a rubric to self-assess their work and their peers' work. By using this activity, the teacher can stimulate 
students' peer-assessment and self-assessment in their learning process.

From the discussion in Writing 3 online course, the teacher designed homework assignments on the Schoology platform after each chapter. The students were given an access code to join the course. The teacher-researcher introduced the platform and train the students on how to use it effectively in their learning. They know how to post their writing, how to interact with their friends and how to use the rubric to self-evaluate their work. On the discussion, students and their classmates had an interaction like a forum, they were able to comment on their peers' work and make a modification for their writing. With the prompt replies from peers and many writing works from other students in the course, students can make their self-assessment and peer-assessment for their learning writing, and thus, improve their writing achievement. Therefore, for an examination about the effects of formative assessment on students' writing achievement, the main activity would be the online discussion board.

For a better understanding of the impacts of formative assessment on students' writing achievement in online courses, this study addresses the following research question:

What are the impacts of online formative assessment on students' writing achievement?

\section{Methodology}

\subsection{Participants}

The target population of this study was fifty EFL third-year students at Kien Giang University, Vietnam. They were selected from two major English classes with ages ranging from 19 to 23. Their English proficiency is generally expected to achieve B1 level in the Common European Framework of Reference for Languages (CEFR). Both groups learned Writing 3 with the teacher-researcher. The students had two weekly sessions of 100 minutes with the researcher.

\subsection{Research design}

This study employed a quasi-experimental design. Accordingly, two intact groups of students were invited to participate in the study with two different learning conditions, with and without online formative assessment's implementation. With this design, the implementation of online formative assessment was undertaken in the experimental group. The impacts of this treatment were then measured by comparing both groups' results from Pre-test and Post-test scores on students' achievement in learning essay writing. To avoid the differential selection caused by major dissimilarities between two groups, the students were selected based on their comparable results in the pre-test at the beginning of Writing 3 course. In terms of class size, both groups are equal with 25 students each.

Firstly, the two groups including the treatment group (TG) and control group (CG) were selected by the researcher. Then, TG and CG students' writing pre-test scores were compared to examine any differences between the two groups before the intervention. Then TG and CG students' writing post-test scores were compared to explore differences in writing performance of students from both groups.

At the beginning of the course, the teacher introduced the two groups the scheme for formative assessment in Writing 3 course including 5 chapters which they had to study during the course namely Writing essay, Comparison/contrast essay, Advantages/ disadvantages 
essay, Causeleffect essay and Problem/solution essay. In class, both groups were asked to discuss some questions relating to the topic. Teachers gave both groups the same lessons in the classroom and the same homework assignments. Before delivering the homework to students, the teacher let students discuss suitable writing skills and provided them with some grammar structures and necessary vocabulary. Then the rubric of each specific essay was introduced. Students had to complete the writing task based on the proposed rubric on the due day. TG students had to submit their assignments onto Writing 3 course on Schoology whereas CG students submitted their paperwork to the teacher or simply wrote their essays on the poster and ticked on the board for correction. After self-assessment at home, students would get immediate peer-assessment from their classmates, and then get the final feedback on their writing from the teacher. The assignments of the online discussion board take up $50 \%$ of the total scores in the course. The other 50\% percent of the marks belong to the final test held by the Faculty.

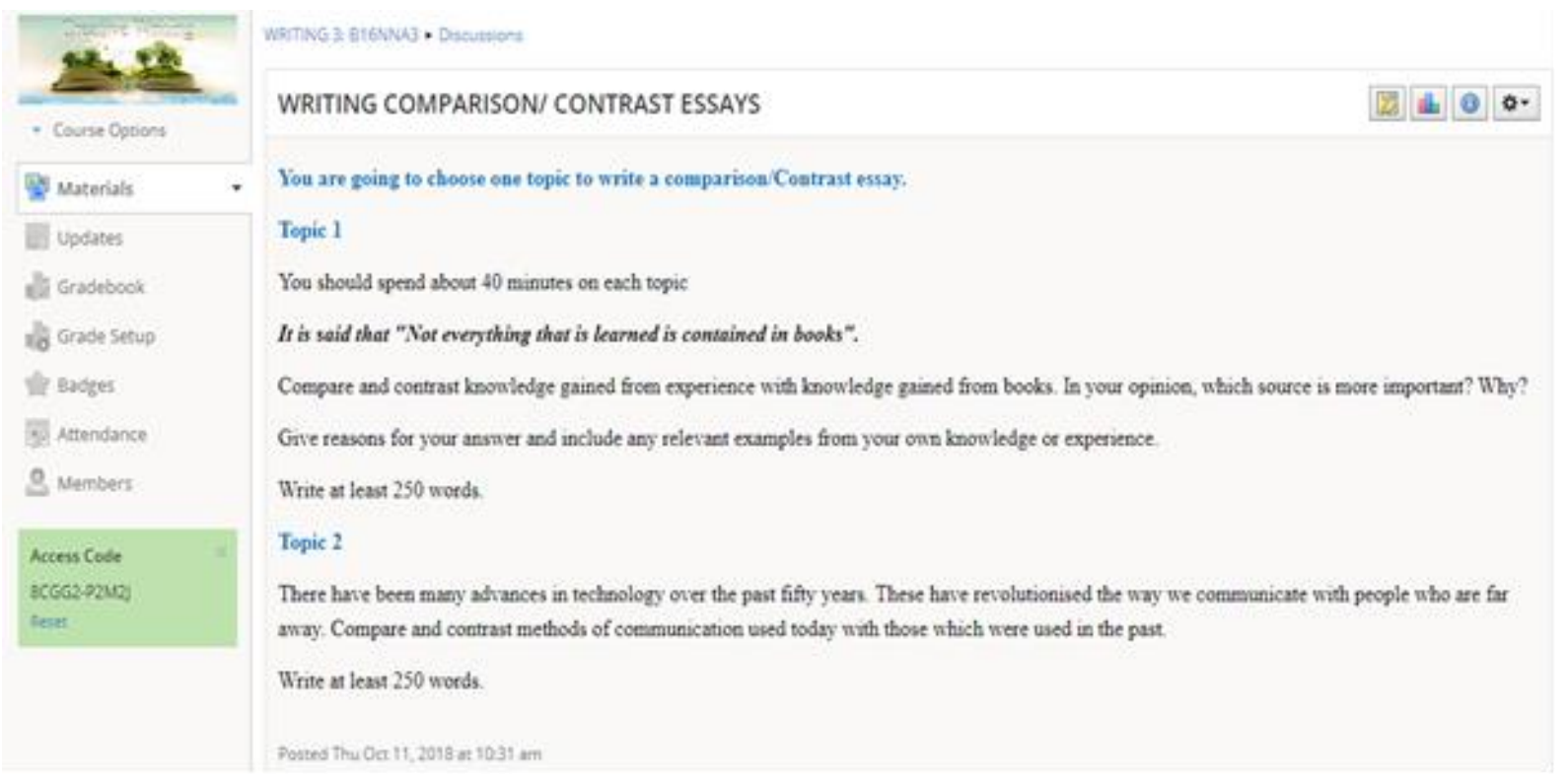

Figure 1. A snapshot of the discussion board on Writing 3 course

\subsection{Platform and development process of formative assessment for TG}

The main online formative assessment tool was an online discussion board to support students' writing activities during the course. Each entry in the discussion thread was used to collect students' work in each unit of the course. There were a total of 5 discussions for writing different kinds of essays during the whole course. Through the discussion board, the teacherresearcher designed specific writing tasks and students used the tool to peer-assess and selfassess their own work during the course. In terms of the 5 writing tasks, the teacher marked students' work based on the rubric. Feedbacks and corrections were also posted to the discussion thread and discussed later in class. The platform of online formative assessment is the web page http://schoology.com whose operations are empowered by the learning management system Schoology. The scheme for implementing an online formative assessment using discussion boards is featured in Table 1 below.

\section{Table 1}


The scheme for the implementation of online formative assessment using online discussion boards

\begin{tabular}{|c|c|c|c|}
\hline Week & Classwork & Week & Classwork \\
\hline 1 & $\begin{array}{l}\text { Introduction to the course } \\
\text { Introduce the Schoology platform } \\
\text { and the discussion board }\end{array}$ & 9 & $\begin{array}{l}\text { Chapter 4: Cause/ effect essay } \\
\text { Activity 4: Write a cause/ effect } \\
\text { essay }\end{array}$ \\
\hline 2 & $\begin{array}{l}\text { Chapter 1: Essay writing } \\
\text { How to write an outline of an essay }\end{array}$ & 10 & $\begin{array}{l}\text { Chapter } 4 \text { : (continued) } \\
\text { Self and Peer correction, teacher's } \\
\text { feedback }\end{array}$ \\
\hline 3 & $\begin{array}{l}\text { Chapter } 1 \text { (continued) } \\
\text { How to write an essay } \\
\text { Training in self-reflection, and peer- } \\
\text { reflection using rubric } \\
\text { Activity 1: Work in group to write an } \\
\text { essay }\end{array}$ & 11 & $\begin{array}{l}\text { Chapter 5: Problem solution } \\
\text { essay } \\
\text { Activity 5: Write a cause/ effect } \\
\text { essay }\end{array}$ \\
\hline 4 & $\begin{array}{l}\text { Chapter 2: Comparison/ contrast } \\
\text { essay } \\
\text { Activity 2: Write a comparison/ } \\
\text { contrast essay }\end{array}$ & 12 & $\begin{array}{l}\text { Chapter 5: (continued) } \\
\text { Self and Peer correction, teacher's } \\
\text { feedback }\end{array}$ \\
\hline 5 & $\begin{array}{l}\text { Chapter 2: (continued) } \\
\text { Self and Peer correction, teacher's } \\
\text { feedback }\end{array}$ & 13 & Revision \\
\hline 6 & $\begin{array}{l}\text { Chapter 3: } \\
\text { Advantages/disadvantages essay } \\
\text { Activity 3: Write a comparison/ } \\
\text { contrast essay }\end{array}$ & 14 & Revision \\
\hline 7 & $\begin{array}{l}\text { Chapter 3: (continued) } \\
\text { Self and Peer correction, teacher's } \\
\text { feedback }\end{array}$ & 15 & Final examination \\
\hline 8 & Mid-term test & & \\
\hline
\end{tabular}

Source: The researcher's data analysis

Each post of students' essay can be followed by multiple reply posts making room for peer-reflection and self-reflection. There are 5 assignments corresponding to 5 chapters of the course program. There is one writing homework assignment every two weeks. The assignment requires students to write one essay about a given topic, post peer-reflections on the assigned classmate's writing, and their self-reflection on their own writing (following the rubric of each essay type). 


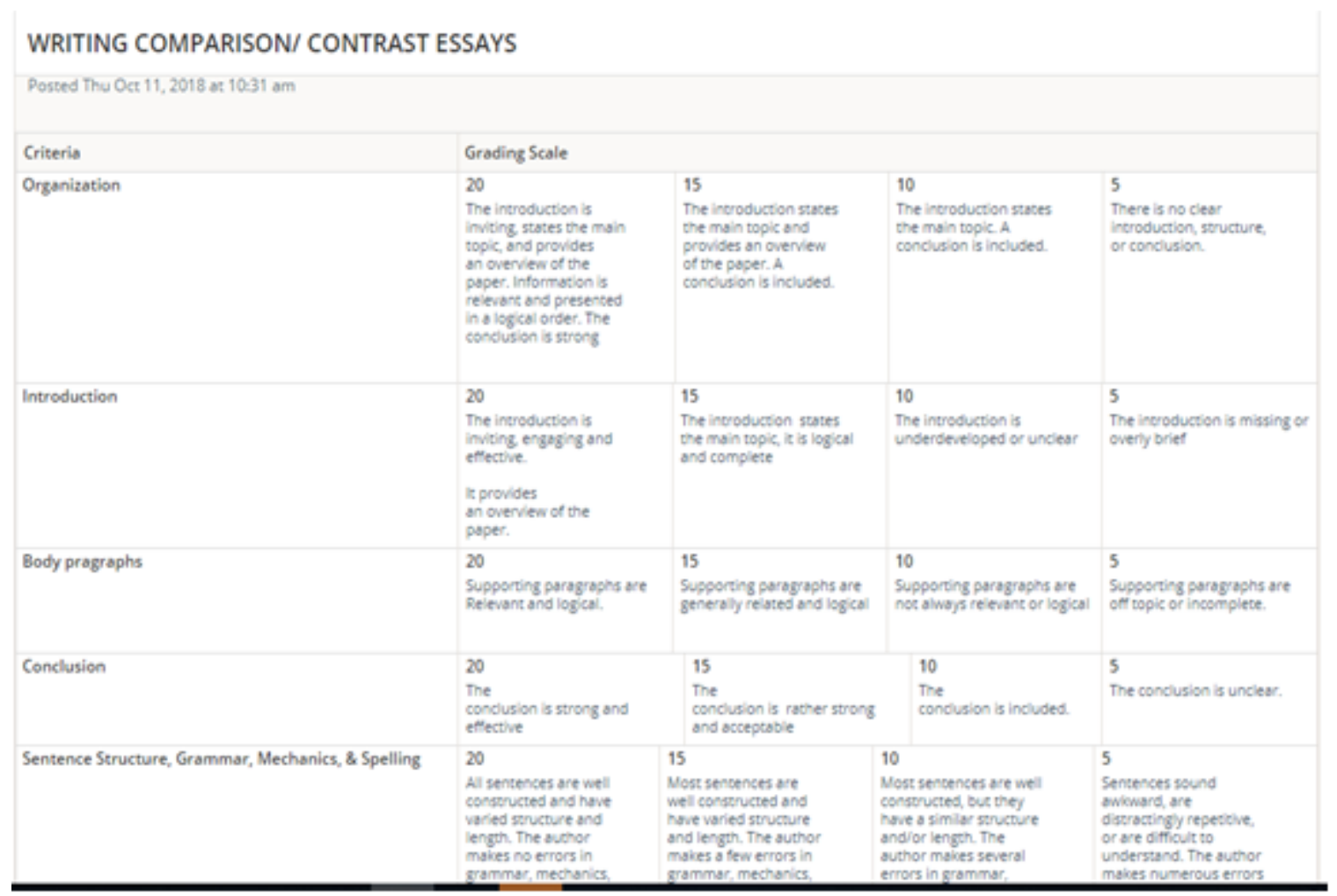

Figure 2. A snapshot of the rubric of comparison/ contrast essay

Table 2

Differences in the requirements for TG and CG students to submit and reflect on writing assignments.

\begin{tabular}{|l|l|l|}
\hline & Control Group (CG) & Treatment Group (TG) \\
\hline $\begin{array}{l}\text { Assignment } \\
\text { submission }\end{array}$ & $\begin{array}{l}\text { Some students prepared their } \\
\text { writing assignments and } \\
\text { submitted their work to the } \\
\text { teacher. }\end{array}$ & $\begin{array}{l}\text { Students prepared their writing } \\
\text { assignment and post it onto Writing 3 } \\
\text { course on Schoology website at } \\
\text { http://schoology.com }\end{array}$ \\
\hline $\begin{array}{l}\text { Peer- } \\
\text { assessment }\end{array}$ & $\begin{array}{l}\text { Some students were invited to } \\
\text { peer-review their peers' } \\
\text { writing. }\end{array}$ & $\begin{array}{l}\text { Students were assigned to prepare peer- } \\
\text { assessment the writing of their peers } \\
\text { The comment was posted in reply to their } \\
\text { classmate's essay. }\end{array}$ \\
\hline $\begin{array}{l}\text { Self- } \\
\text { assessment }\end{array}$ & $\begin{array}{l}\text { Students self-assess their } \\
\text { writing after listening to peer- } \\
\text { feedback. The students: } \\
+ \text { self-evaluate their writing } \\
+ \text { re-write their essay and } \\
\text { resubmit it. }\end{array}$ & $\begin{array}{l}\text { After receiving peer-feedback, students: } \\
+ \text { self-evaluate their writing } \\
\text { + re-write their essay and posted again. }\end{array}$ \\
\hline
\end{tabular}


Source: The researcher's data analysis

\subsection{Instruments}

This study employs students' writing pre-test and post-test as instruments to collect data and examine the impact of online formative assessment on students' achievement in learning writing skills.

\subsubsection{Writing pre-test and post-test}

The writing pre-test was the final test of Writing 2. The students were asked to write a paragraph about 150-200 words in 30 minutes. Two raters were invited to mark the students' writing using a 5-criteria rubric of paragraph writing including topic sentences, supporting detail sentences, concluding sentences, sentence structures, mechanics and grammar. The posttest was the final test of Writing 3 and students had 50 minutes to complete the test. As required by English Department, the writing task was rated by two scorers using a holistic scoring rubric. It was composed of the six categories such as organization, introduction, body paragraphs, conclusion, sentence structure, grammar \& mechanics and spelling. Students' writing was assessed and rated on a scale of even scores from zero to five (0-5 scale). TG and CG students' pre-test and post-test scores were then inputted into SPSS software version 22.0 for further statistical examination and analyses.

\subsubsection{Statistical methods for students' writing pre-test and post-test}

First, the reliability of students' writing pre-test and post-test was checked by the Kappa measure on SPSS. Results of Kappa statistic measure let the researcher know the level of agreement between the two scorers of the writing tests, and whether data obtained from those writing tests were reliable for further statistic tests. Then two independent sample Tt-tests were conducted on TG and CG students' scores of their writing pre-test and post-test. Specifically, an independent sample t-test was used to examine differences between TG and CG students' writing achievement before applying online formative assessment. Then another independent sample T-test was conducted on TG and CG students' writing posttest scores to examine whether there was a statistically significant difference between TG and CG students' writing achievement after implementing the online formative on Schoology. In other words, this test was to understand the impact of online formative assessment on students' achievement in the writing course.

\section{Results}

4.1. Inter-rater reliability of $T G$ and $C G$ students' scores rated by two scorers in writing pre-test and post-test

Inter-rater reliability analyses using the Kappa statistic were performed to determine consistency between the two scorers, that is the agreement level between the scorers in the writing pre-test and post-test for both groups - treatment group (TG) and control group (CG). Table 3 and 4 below presents the Kappa values of the analyses. 


\section{Table 3}

Inter-rater reliability of TG and CG students' scores rated by two scorers in writing pre-test

\begin{tabular}{|c|l|l|r|r|r|r|}
\hline \multicolumn{7}{|c|}{ Symmetric Measures } \\
\hline \multicolumn{2}{|c|}{$\begin{array}{l}\text { Inter-rater } \\
\text { reliability }\end{array}$} & Value & $\begin{array}{c}\text { Asymp. Std. } \\
\text { Error }^{\mathbf{a}}\end{array}$ & $\begin{array}{c}\text { Approx. } \\
\mathbf{T}^{\mathbf{b}}\end{array}$ & $\begin{array}{c}\text { Approx. } \\
\text { Sig. }\end{array}$ \\
\hline $\begin{array}{c}\text { TG's } \\
\text { writing pre-test }\end{array}$ & $\begin{array}{l}\text { Measure of } \\
\text { Agreement }\end{array}$ & Kappa & .815 & .081 & 11.456 & .000 \\
\cline { 2 - 7 } & N of Valid Cases & 25 & & & \\
\hline $\begin{array}{c}\text { CG's writing } \\
\text { pre-test }\end{array}$ & $\begin{array}{l}\text { Measure of } \\
\text { Agreement }\end{array}$ & Kappa & .719 & .095 & 9.436 & .000 \\
\cline { 2 - 7 } & N of Valid Cases & 25 & & & \\
\hline
\end{tabular}

a. Not assuming the null hypothesis

b. Using the asymptotic standard error assuming the null hypothesis.

Source: The researcher's data analysis

The inter-rater reliability of TG students' scores in writing pre-test, CG students' scores in writing pre-test had Kappa values of 0.81 and 0.71, respectively ( $\mathrm{p}<.0 .001)$, 95\% CI (0.504, 0.848). As argued by Landis and Koch (1977), a Kappa value from 0.7 is preferred by most statisticians as a good level of agreement. Hence, TG and CG students' scores in these two tests were considered reliable for further analysis.

\section{Table 4}

Inter-rater reliability of TG and CG students' scores rated by two scorers in writing post-test

\begin{tabular}{|c|c|c|c|c|c|c|}
\hline \multicolumn{7}{|c|}{ Symmetric Measures } \\
\hline \multicolumn{3}{|c|}{$\begin{array}{l}\text { Inter-rater } \\
\text { Reliability }\end{array}$} & Value & $\begin{array}{c}\text { Asymp. Std. } \\
\text { Error }^{\mathrm{a}}\end{array}$ & $\begin{array}{c}\text { Approx. } \\
\mathbf{T}^{\mathbf{b}}\end{array}$ & $\begin{array}{l}\text { Approx. } \\
\text { Sig. }\end{array}$ \\
\hline \multirow{2}{*}{$\begin{array}{c}\text { TG's } \\
\text { writing post- } \\
\text { test }\end{array}$} & $\begin{array}{l}\text { Measure of } \\
\text { Agreement }\end{array}$ & Kappa & .855 & .075 & 10.508 & .000 \\
\hline & \multicolumn{2}{|c|}{$\mathrm{N}$ of Valid Cases } & 25 & & & \\
\hline \multirow[t]{2}{*}{$\begin{array}{c}\text { CG's writing } \\
\text { post-test }\end{array}$} & $\begin{array}{l}\text { Measure of } \\
\text { Agreement }\end{array}$ & Kappa & .761 & .087 & 9.449 & .000 \\
\hline & \multicolumn{2}{|c|}{$\mathrm{N}$ of Valid Cases } & 25 & & & \\
\hline \multirow[t]{2}{*}{ Total } & $\begin{array}{l}\text { Measure of } \\
\text { Agreement }\end{array}$ & Kappa & .817 & .056 & 16.330 & .000 \\
\hline & \multicolumn{2}{|c|}{$\mathrm{N}$ of Valid Cases } & 50 & & & \\
\hline
\end{tabular}

a. Not assuming the null hypothesis.

b. Using the asymptotic standard error assuming the null hypothesis.

Source: The researcher's data analysis

Similarly, the inter-rater reliability of TG students' scores in writing post- test TG students' scores in writing post-test, and CG students' scores in writing post-test had Kappa value of 0.85 and 0.76 which is considered a high agreement level. Hence, TG and CG students' scores in these two tests were considered reliable for further analysis.

\section{skills}

\subsection{The impacts of online formative assessment on students' achievement in writing}


To investigate the impacts of online formative assessment on students' writing achievement, TG and CG students' writing pre-test and post-test scores were compared. First, the study tries to examine the statistically significant differences (if any) between TG and CG's writing pre-test scores before the treatment so that the difference between the two groups in the post-test scores was valuable. Table 5 shows the means of 2.74 and 2.93; and the standard deviations of 0.84 and 0.81 for TG and CG students' writing pre-test scores, respectively.

\section{Table 5}

Mean difference of two groups' scores in writing pre-test

\begin{tabular}{|l|l|l|r|r|}
\hline Group & $\mathbf{N}$ & Mean & Std. Deviation & \multicolumn{2}{|l|}{ Std. Error Mean } \\
\hline TG & 25 & 2.74 & 0.84 & .16 \\
\hline CG & 25 & 2.93 & 0.81 & .16 \\
\hline
\end{tabular}

Source: The researcher's data analysis

As presented in Table 6, the independent sample t-test yielded $t(48)=-.81, p>.05$, illustrating that TG and CG students' writing scores did not differ prior to the intervention.

\section{Table 6}

Comparison of TG and CG students' Writing pre-test scores

\section{Independent Samples Test}

Levene's Test
for Equality
of Variances
F Sig.

Pre-test

Equal
variances
assumed

Equal

variances

not

assumed t-test for Equality of Means

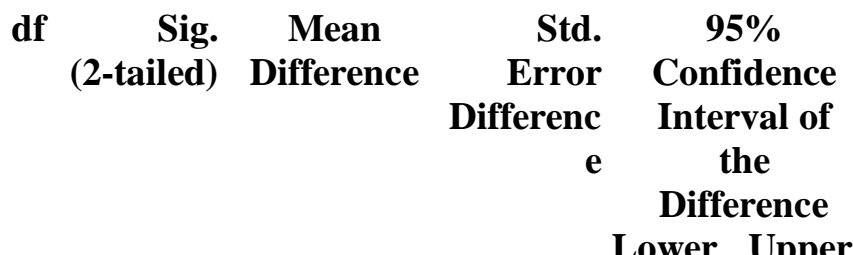

Lower Upper

$\begin{array}{llllllllll}.010 & .920 & -.812 & 48 & .421 & -.3800 & .4682 & -1.3213 & .5613\end{array}$

Source: Data analysis result of the research

Then, the results of the independent sample t-test on TG and CG's writing posttest scores showed the means of 3.85, and 3.35; and the standard deviations of 0.71 and 0.87 for TG and CG, respectively (see Table 7). 


\section{Table 6}

Mean difference of two groups' scores in writing post-test

\begin{tabular}{|l|l|l|r|r|}
\hline Group & N & Mean & Std. Deviation & \multicolumn{2}{|c|}{ Std. Error Mean } \\
\hline TG & 25 & 3.85 & 0.71 & .14 \\
\hline CG & 25 & 3.35 & 0.87 & .17 \\
\hline
\end{tabular}

Source: The researcher's data analysis

Then, the independent sample t-test yielded $\mathrm{t}(28)=2.15, \mathrm{p}<.05$, suggesting that there was a statistically significant difference between TG and CG's writing test scores after the course (see Table 4.6). In other words, in the final writing test of the course, TG students who learned with an online formative assessment on Schoology outperform CG students who learned with the traditional assessment method.

\section{Table 7}

Comparison of TG and CG students' Speaking post-test scores

Independent Samples Test

\section{Levene's Test for Equality of Variances}

t-test for Equality of Means

F Sig. $T$ df $\quad$ Sig. Mean $\quad$ Std. $95 \%$ Confidence (2-tailed)Difference Error Interval of the Differenc Difference

e

Lower Upper

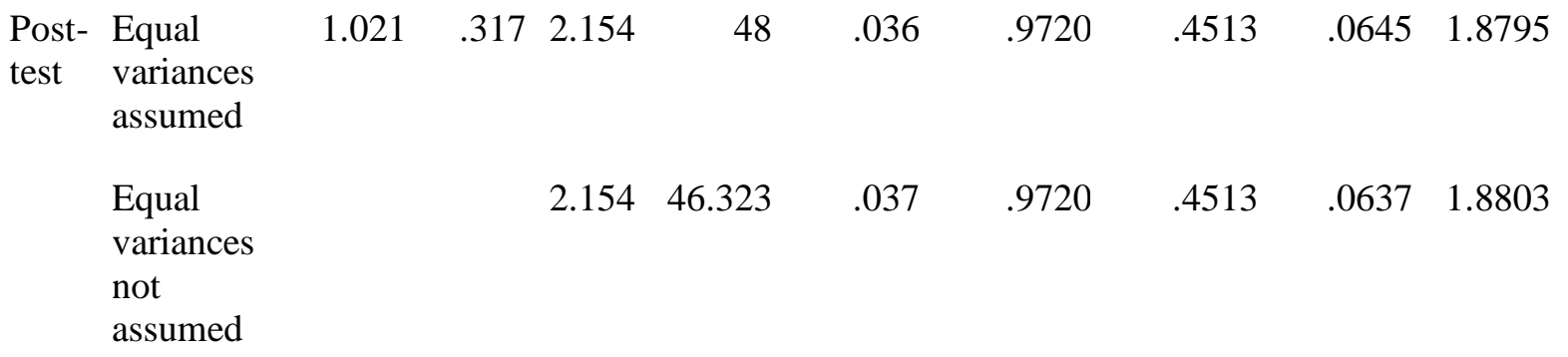

Source: Data analysis result of the research

\section{Discussion}

The finding revealed that online formative assessment had positive effects on students' learning outcomes. The implementation of online formative assessment, specifically using an online discussion board in the writing course could stimulate students' self-assessment and peer assessment and thus improve their writing achievement. First, peer-assessment among the students via the direct comments on their peers' writing on the course helped students recognize 
their mistakes. It also fosters students' motivation in learning as they get prompt replies from their peers. Next, from the correction learning from peer-assessment, students can reflect on their own work and make correction by themselves. Self-assessment on the discussion board might also trigger students' outcome and learner autonomy in their learning process.

The result was in line with Ghadi's study (2016) when Iranian EFL learners in the experimental group had outperformed in both writing and autonomy scale administered at the end of the study. The participants also showed their positive beliefs about the implementation of electronic peer assessment and web-based tools. Similarly, this finding seems to accord with the outcomes of Zainnuri and Cahyaningrum (2017)'s experimental English classes which employed online peer review through discussion via Schoology to enhance EFL college students' argumentative writing. The subjects from the interview agreed that online peer review through discussion board can help enhance their proficiency in argumentative writing. Similar to the students of that research, participants of the current study experienced significant changes in their ability to use written English. More specifically, the activities assigned to them including self-assessment and peer-assessment on the discussion board have encouraged them to think more critically. It may be suggested that online formative via Schoology help develop student's writing skills. However, the research finding was inconsistent with prior research by Aliweh (2011) as the online portfolios did not yield significant effects on students' writing competence due to the interference of different variables which are the least controllable in online research.

\section{Implications and conclusion}

The current research revealed the effectiveness of formative assessment on virtual learning environments in enhancing students' achievement in their writing learning. The findings also suggested several implications for the implementation of formative assessment in teaching writing at the tertiary level.

First, peer-reflection and self-reflection guidelines provided to students at the beginning of the course possibly clarified how students could identify the requirement of their writing assignments, the rubric for their essay, as well as how to self-assess their postings. Therefore, students could engage more in completing their writing assignments. Students' increased involvement in learning could probably lead to their improved achievement after the course.

Second, the requirement for using English constantly on online discussion boards could help the participants write English better. They have time and room to find their mistakes due to their peer-assessment and the existent of their postings on the course. When students can self-evaluate their work and read their peers' writing on an online course, they might find it more convenient and interesting than doing similar work in the traditional class. They can learn much from modifying their own word and comparing it with their peers' work. As a result, their writing will be improved gradually.

Third, the internet-based course helps students save time to approach their friends' writing through the internet. They found the discussion board useful when they could not meet face-to-face to discuss and share ideas, which could be suitable with their busy schedule.

However, so as to encourage all students to engage with the online discussion board, the 
teacher should establish a mandatory condition (Weisskirch \& Milburn, 2003). This includes the number of postings, responses as well as the deadline for each specific assignment. Furthermore, the support and intervention of the teacher during the course are really significant. Prompt reply and encouragement from the teacher may help students realize the value of their contribution. The students who actively participate in the online discussion board tend to achieve a better final grade.

In conclusion, on the learning management system Schoology, formative assessment can help EFL students improve their writing achievement and be more involved in their learning process.

\section{References}

Aliweh, A. M. (2011). The effect of electronic portfolios on promoting Egyptian EFL college students' writing competence and autonomy. Asian EFL Journal, 13(2), 90-132.

Ardi, P. (2017). Promoting learner autonomy through Schoology M-Learning platform in an EAP class at an Indonesian university. Teaching English with Technology, 17(2), 55-76.

Bachman, L. F. (1990). Fundamental considerations in language testing. Oxford, UK: Oxford University Press.

Black, P., \& Wiliam, D. (1998). Inside the black box: Raising standards through classroom assessment. London, UK: Granada Learning.

Boud, D. (1995). Assessment and learning: Contradictory or complementary? In P. Knight (Ed.), Assessment for learning in higher education. London, UK: Kogan Page.

Chappuis, S., \& Chappuis, J. (2007). The best value informative assessment. Educational Leadership, 65(4), 14-18.

Cheng, L., Rogers, T., \& Hu, H. (2004). ESL/EFL instructors' classroom assessment practices: Purposes, methods and procedures. Language Testing, 21(3), 360-389.

Clarke, S. (2005b). Formative assessment in the secondary classroom. London, UK: Hodder Murray.

Cowie, B., \& Bell, B. (1999). A model of formative assessment in science education. Assessment in Education: Principles, Policy \& Practice, 6(1), 101-116.

Dang, T. T. (2012). Learner autonomy perception and performance: A study on Vietnamese students in online and offline learning environments. (Unpublished doctoral dissertation). La Trobe University, Australia.

Ghadi, S. A. (2016). The effect of employing electronic peer assessment on Iranian EFL learners' writing ability and autonomy. Theory and Practice in Language Studies, 6(12), 2272.

Gikandi, J. W., Morrow, D., \& Davis, N. E. (2011). Online formative assessment in higher education: A review of the literature. Computers \& Education, 57(4), 2333-2351.

Gipps, C. (1994). Beyond testing: Towards a theory of educational assessment. London, UK: The Falmer Press. 
Graham, S., Harris, K., \& Hebert, M. (2011). Informing writing: The benefits of formative assessment. A report from carnegie corporation of New York. New York, NY: Carnegie Corporation of New York.

Harsch, C. (2014b). Formative assessment and feedback. Unpublished manuscript, Applied Linguistics, University of Warwick, Coventry, UK.

Hattie, J. (2009). Visible learning: A synthesis of over 800 meta-analyses relating to achievement. New York, NY: Routledge.

Hattie, J. (2012). Visible learning for teachers: Maximizing impact on learnings. New York, NY: Routledge.

Irons, A. (2008). Enhancing learning through formative assessment and feedback. New York, NY: Routledge.

Kahl, S. (2005). Where in the world are formative tests? Right under your nose!. Education Week, 25(4), 11.

Landis, R. J., \& Koch, G. G. (1977). The measurement of observer agreement forx categorical data. Biometrics, 33(1), 159-174. doi:10.2307/2529310

Li, H. (2012). The researches on correlation between learner autonomy and formative assessment. Psychology Research, 8, 85-89.

Schoology. (2015). Schoology named finalist in higher ed and K-12 education technology in CODiE awards. Retrieved March 11, 2019, from https://www.Schoology.com/news/codie-finalist-2015

Wiliam, D., Lee, C., Harrison, C., \& Black, P. J. (2004). Teachers developing assessment for learning: Impact on student achievement. Assessment in Education Principles Policy and Practice, 11(1), 49-65. doi:10.1080/0969594042000208994

Weisskirch, R. S., \& Milburn, S. S. (2003). Virtual discussion: Understanding college students'electronic bulletin board use. The Internet and Higher Education, 6, 215-225. doi:10.1016/S1096-7516(03)00042-3

Submitted June 2009. Final Version July 2010. Accepted August 2010.

Yu, H., \& Li, H. (2014). Group-based formative assessment: A successful way to make summative assessment effective. Theory and Practice in Language Studies, 4(4), 839844.

Zainnuri, H., \& Cahyaningrum, D. (2017). Using online peer review through discussion via schoology to enhance college students' proficiency in argumentative writing: A case study. Proceedings of the International Conference on Teacher Training and Education 2017 (ICTTE 2017). doi:10.2991/ictte-17.2017.55 